\title{
The Influence of Institutions on Variation in Innovativeness of Small Businesses and Occupational Structure: A Case Study in Sri Lanka
}

\author{
UPANANDA W. A. \\ Department of Banking and Finance \\ Faculty of Business Studies and Finance \\ Wayamba University of Sri Lanka \\ SRI LANKA \\ uwitta@yahoo.com
}

\begin{abstract}
:-
Growth of the Sri Lankan economy in the last three decades, according to published data, is uneven or spurious. Even though internal and external shocks have been cited as reasons for this uneven pattern, it is unlikely to explain huge continuous variation in economic growth in recent years. Also such variation may not supported by the statistics in occupational structure of the country. But in other countries such as India and European countries economic growth has strong relationship with the occupational structure. Economic growth of those countries is characterized by sequential transformation: agriculture dominated economies to industrial economies and then to services economies. Recent research in Europe suggests that economic growth is directly related to innovativeness of small businesses which claims larger share of employment and theorizes that relationship between economic development and entrepreneurship takes U-shape. Entrepreneurship of an economy is represented by the population engaged in productive self-employment. Researchers who support this argument argue that entrepreneurs move along a spectrum of innovativeness. At the lower end of this spectrum lies self-employment for earn a living while the other extreme is occupied by the innovative small businesses. These innovative businesses are operated by individuals who believe that they could earn better income from business than their wage employments. This paper argues that institutional environment could be the major factor which determines the position of small business on the innovativeness spectrum. The basis of this argument is the uncertainty of outcome engaging in small businesses due to uncertain institutional environment. Institutional environment, according to scholars, consisted of political and regulatory, economic and social cultural and technological institutions. Selecting 13 cases after screening 98 cases in different provinces across the country this study found that entrepreneurs who sought small businesses as an earn-a-living stay at the lower end of innovativeness spectrum while other end is occupied by individuals who believe his capability of earning more than a wage employment. Indepth studies of these 13 cases reveal that adopt survival strategies than growth strategies.
\end{abstract}

Keywords:- Entrepreneurship, Economic growth, Occupational Structural, Institutions 


\section{Introduction:}

In pre-independence era Sri Lankan economy had been described as a dual economy that consisted of peasant subsistence economy and plantation economy. According to Central Bank Reports, contribution from agriculture, industry, and services sectors to GDP were 46.3, 19.6, and 36.9 percent respectively in 1950. In 2005 the contribution to GDP was changed to 17.2, 27, and 55.8 percent respectively (Central Bank Annual Reports). Moreover, employees engaged in those sectors in 1963 were 53, 10, and 37 percent respectively while it was changed to $32.8,26.0$, and 41.2 percent in 2004 (Central Bank Annual Reports). The composition of occupational structure, as shown above statistics, is more similar to that of a developed country such as UK, USA, or Japan. Then it is important to examine how and why occupational structure became similar to that of developed country while economic structure remain more similar to that of a developing country. The huge variations in occupation structure (manufacture and services sectors) without marked decline in employment in agriculture sector is a factor to be examined which this study argues a mismatch which cannot sustained a stable economic growth. More importantly changes in OECD countries over the same period of time show that an increased contribution to GDP by services and industry sectors but with decline in contribution from agriculture sector. Therefore there could be a mismatch between occupational structure and economic structure which could not sustain a sustainable economic growth. Hence this study argues that population engaged in small business are not attempt to increase the wealth creating potential of their enterprises and adopt survival strategies rather than innovative strategies. Then it worthwhile to investigate why small business-owner population does not move towards more wealth creating activities rather than staying in low innovative strategies.

Currently, developed countries have fully understood importance of entrepreneurship and took various measures to stimulate innovative entrepreneurship. European Council Meetings in Lisban in 2000 and again in 2002 endorsed that the contribution of entrepreneurship towards economic growth (Thurik and Wennekers, 2004) is significant. Wennekers, Stel, Carree, and Thurik, (2007) researching on the relationship between the level of business ownership and economic growth found that it takes U-shape relationship. They further stated, smallness, lower entry barriers, changing consumer preferences, declining transaction costs, trend in occupational preference towards more autonomy and self-realization are the factors for this $U$ shape. Also they attributed this negative relationship to the spectrum of non-innovative entrepreneurship - innovative entrepreneurship. They posit that moving entrepreneurs along this spectrum may influenced by the institutional context. That is say when institutional context is favorable entrepreneurs attempt to pursue more innovative opportunities and reverse move when the institutional context is not favorable. $\mathrm{Lu}$ (1994) confirming this argument states that societal rule influences the distribution of entrepreneurship between productive entrepreneurship and unproductive entrepreneurship. Uncertainty in institutions, $\mathrm{Lu}$ further states, may substitute productive entrepreneurship with unproductive entrepreneurship.

Then it is important to understand what makes the entrepreneurship productive and more innovative. 
Schumpeter (1934; Hayek, 1945; Carson, 1985) stated that institutional environment is the basis for all incentive which stimulate the process of entrepreneurship. Shane (2003) further elaborates that both incentives and legitimacy of entrepreneurship depend upon the institutional environment. Researching on illegal trade in Nigeria, Fadhansi and Rosa (2002) contends that the distribution of productive and unproductive forms of entrepreneurship may depend on the institutional environment in Nigerian cross-broader regions which favors illegal trading. Taking these arguments further, and applying mismatch between the economic structure and occupational structure, this study raises the research question of this study in the next section.

\subsection{Research Question \& Objective of the Study}

Table 1.1 (please see appendices) gives the sectorial share of the Sri Lanka economy and the table 1.2 shows the employment and GDP share of the economy. To show the mismatch in Sri Lanka ,Table 1.3 and 1.4 gives the occupational structure of and sectorial composition of the Indian economy (please see appendices). Comparing above 1.1 and 1.2 tables with 1.3 and 1.4 tables one can understand that there is a mismatch between Sri Lankan economic and occupational structure which may influence the economic growth. Then this study rises the research question what makes this mismatch between occupational structure and economic structure'.

\section{Literature Review}

\subsection{Growth Theories \& Entrepreneurship}

Schumpeter (1912) pioneered in establishing relationship between economic growth and entrepreneurship of a country. His Theory of Economic Development had identified creative destruction as the role of entrepreneur in economic growth. This had been evident in 1970s and 80s with the growth of small firms which resulted increased numbers of entrepreneurs in European countries. Researchers identified this as entrepreneurial economy and named as Mark I Schumpeterian regime. He also predicted that small firms will fade away due to its inherent inefficiencies and growth of large firms due to investment in Research and Development and this has been identified as Schumpeterian Mark II regime which characterizes with the creative accumulation. Audretsch and Thurik (2001) conceptualized these regimes as managed and entrepreneurial economies. Wennekers and Thurik (1999) states that small business is a vehicle for entrepreneurship and contributes to economic growth, political stability and competitive advantage. However they were not able to predict consequences of political and economic un-stability on entrepreneurship. This paper attempts to explore the impact of ethnic, political and economic turbulence on entrepreneurship. Kaynesian economists which linked economic growth into factors affecting aggregate demand but failed to explain high unemployment and stag-flation in 1970s and 1980s (Ahuja 2003).

\subsection{Theories of Entrepreneurship}

The domain of entrepreneurship has been defined as the study of sources of opportunities, the process of discovery, evaluation, and exploitation of opportunities and the individuals who discover, evaluate and exploit them (Shane and Venkataraman, 2000). Sources of opportunities provides the context for creating enterprises by agents (entrepreneurs) who specifies, interprets, and act upon those sources in various 
forms. Entrepreneurship used in this study also adopts the definition of Venkataraman (1997), Shane and Venkataraman (2000), as Entrepreneurship is an activity that involves the discovery, evaluation and exploitation of opportunities to introduce new goods and services, ways of organizing, markets, processes, and raw materials though organizing efforts that previously had not existed.

\subsection{Institutional environmental context}

Institution environment is consisted of political and regulatory, economic, social and cultural, and technological contexts. In Sri Lanka political and regulatory had become turbulent at the turn of the decade 1970. Inward looking economic policies, land reforms, constitutional changes are main feature with low economic growth rate. Economic environment had been varying since independence in response to political and regulatory changes. The economic growth rate is fluctuating from -1.4 to 8.2 percent since independence. Cultural values and norms are changing corresponding to the political and economic changes taken place. Notably, ethnic conflict between North and South had changed in institutional environment of the country greatly. The incidence took place as a result of this ethnic war completely de-established the institutional environment completely creating uncertainty about the future of individuals, firms and government. Institutional changes in turn become the sources of opportunity and Bhide (2000) states that 50 percent of the fastest growing companies (Inc.500) initiated their business in response to specific change in technology, regulatory, or other external factors. However he did not explained the consequences of rapid changes in venture creation process.

\subsubsection{Political And Regulatory}

Although the period under this study is three decades $(1975$ - 2005), it is important to trace back to incidence taken place in the period of $1970-1977$. This is unique opportunity to examine entrepreneurial activities in response to inward looking import substitution policies. Emerging insurrection activities in 1971 had manifested the ideology of rural youth. This was the first rebellion movement took place in Sri Lanka to seize power through armed struggle. Land reform of 1972 had paved the way to major structural changes in the economy. Land ceiling had fragmented the private owned lands and reduced the productivity of those lands. On the other hand it was instrumental in easing the pressure for land by both rural and urban. Liberalization of the economy in 1978 was a major political change that changed the country's institutional environment completely. As a result entrepreneurs who thrived under protection policy of government vanished paving way to emerge another set of entrepreneurs who were looking outward and producing for export. After the assassination of president in 1993, Peoples Alliance (PA) government came into power with a slight majority in 1994. The re-elected PA government in 2000 was far weaker than the previous coalition government. In March 2001, there was a coup on the Leader of Opposition.

\subsubsection{Economic environment}

Economic environment of the country can be divided into two main policy regimes: import substitution inwardlooking policies and export oriented outward-looking, liberalized economic policies. Sectorial changes with respect economic environment are given in the table 2.1. Sri Lankan dual economy started to disintegrate since independence owing to investment on peasant 
agriculture. As a result paddy production doubled between 1947-49 and 1959-61). However the sectorial structure remained unchanged until 1960s. The trade surplus inherited from pre-independence period dried up due to welfare programme launched by respective governments. Kelagama (2006) describes this condition as interlocking; welfare programmes depends on plantation taxes and these taxes depend upon world market prices. When world market prices go down foreign exchange crises comes and solution to this crisis was import substitution. 1970-77 period was a period restrictions both locally and foreign. State intervention in the market was common feature during this regime (Kelegama, 2006). Industries both indigenous and manufacturing were heavily dependent upon intermediate capital goods imported. Due to foreign exchange restriction productive capacity of the country starved resulting in stagnation of economic growth.

Government came into power in 1978 took measures for rapid development by introducing export -led industrialization policies and incentives for foreign direct investment. Removing food subsidy and huge public investment through accelerated Mahaweli development programme were key features in the liberalized economic regime from 1977 1997. Remittance from Middle Eastern countries also 0.5 percent of GDP in 1978 to 5.5 percent by 1982 (Kelagama, 2006: 53). Exports from garment industries increased from 2.1 percent of total export to 16 percent by 1992 (Kelagama, 1992: 260). Foreign exchange scarcity prevailed in 1970-1977 was not a problem after economic liberation (Athukorala \& Jayasuriya, 1994). However, the growth environment began disappear with the onset of ethnic violence that erupted in 1983.

\subsubsection{Insurrection Activities and Ethnic Conflict}

Insurrection activities and North-East Conflict brought new burden to growing economy in 1983 and onwards. Defense expenditure which was 1.2 percent of GDP in 1981 rose to 6 percent in 1996 (Central Bank Reports). There were three ethnic wars called 'Elam Wars'. First Elam war started in 1983 and continued until 1987. Second Elam war started in 1990 and continued until 1994. Third war started in 1995 and continued to 2001. Kalegama (2006) described Elam wars as the most intractable problem the country ever faced and blighted its political, social and cultural traditions and has become the biggest obstacle to the country in realizing its full potential.

Assassination of president in 1993 changed the political leadership and in 1994 August new government came into power but with same liberalized policies. However the economic growth rate limited to 4.8 percent during 1990-1993 period (Central Bank Reports). Defence Levy was increased to 4.5 percent and Save the Nation contribution was introduced (3 percent over Rs. 30,000.00 monthly emolument) in 1995 . As government was increasing defence spending LTTE targeted economic centres: Oil Refinery in October 1995, Central Bank in January 1996, Colombo Sea Port in April 1996, and Colombo Stock Market in October 1997 are recorded as such incidences. Devolution proposals were introduced in 1995 as a settlement for Elam War but were not successful due to strong opposition and failure to get two third majorities at the Parliament.

In March 2001 LTTE captured Elephant Pass and periphery of Jaffna and increased oil prices in 2000 made foreign reserves weak and was able to sustain 
only two months of imports (Kelegama, 2006). In addition the government had to face four internal shocks : May 2001 electricity shortage, severe drought which impacted on agricultural productions, LTTE's airport attack, Economic recession due to September 11 terrorist attack on World Trade Centre (biggest importer of Sri Lankan garment). In December 2001 UNP government came into power after Rs. 600 million worth of election. During this time Sri Lanka experienced the worst economic growth of -1.4 percent. In $2002 \mathrm{MoU}$ was signed with the LTTE with intervention of Norwegian Government.

Economic Cost of the ethnic conflict had been calculated and estimated to 168 percent of the 1996 GDP for the period from 1984 to 1996. Apart from direct economic cost following indirect impacts were observed: uncertain investment climate, brain drain, loss of man power (about 65, 000 people have killed by the war), frequent security checks and road blocks, delays and loss of productivity, army deserters involvement in underworld activities. In the meantime LTTE built its own economy with the remittance from Tamil Diaspora, illegal narcotic smuggling, and arm sales. However this economy is reacting against the formal economy of Sri Lanka. Sex trade in North Central Province was flourishing to serve the armed forces kept standby (Kelagama, 2003: 166).

\subsubsection{Industrial Environment and Technological Advancement}

Industrial Development of policy in Sri Lanka can be categorized in to four periods: Continuation of colonial open economy from 1948 to 1956 , Closed up economy from 1956 to 1977 , Opening up from $1977-89$ first phase and Opening up 1990 to 2004 second phase (Athukorala and Rajapathirana: 2000:34). Foreign exchange crisis arose in 1960s force government to promote import substitution industries and imposed stringent control on foreign exchange coupled with complete ban on luxury imports. State owned enterprises (SOEs) were introduced in 1970-77 regime in order to raise employment, output growth and national savings. However SOE experience was not encouraging due to following reasons: None of the SOEs were set up on the basis of economic analysis, second they were neither economically efficient nor financially viable, and the third was inefficient management due to political patronage (Athukoral and Rajapathiran, 2000.

The opening up first phase from 1977 89 had given rapid economic growth. Average annual economic growth rate sprang up from 2.9 percent to 6 percent annual average growth rate. Athukorala and Rajpathirana (2000:39) describe this situation as shifting from structural adjustment to politically appealing investment project (Mahaweli project). In other words, Mahaweli development project government investment was directed towards solo entrepreneurship neglecting innovative entrepreneurship. Almost all the investment was made on the lower end of entrepreneurship. Accelerated Mahaweli development Programme, island-wide housing construction programmes (Gam Udawa), Construction of new administrative capital (Jayawardan Pura). Total investment rose from 15 percent of GDP in 1970 to 31 percent in 1980 (Athukoral and Jayasooriya, 1994:78). The major characteristic of Second phase of opening up (1990-1996) privatization programme which started in $1989 . \quad$ Removing ownership of foreign joint venture outside the free trade zones was another measure to boost the export-oriented economic regime. In sum as Athukorala and Rjapathirana (2000) states "A country starts with a liberal economy then it goes through a phase of import 
substitution base industrialization. Contrary to this strategy trade liberalization switch consumer goods imports to intermediate goods and raw materials and impose export bias. Again protectionism imposes and finally trade liberalization and effort to reduce the bias against exports.

\subsubsection{Creativity and Innovation (Technological Environment)}

Creativity and innovation are two concepts which are inseparable from entrepreneurship. According to Hitt (2000) creativity is having new idea and innovation is doing something with that idea. Creativity may lead to innovation but not necessarily same thing. Similarly entrepreneurship can be distinguished from innovation. Entrepreneurship is more of a process which transforms innovation into market opportunities to or competitive advantage (Hitt, 2000). Currently we are in information and knowledge economy. I tis estimated that there are 275.5 million people online worldwide (Nua, 2000). Rate of change of technology and technological diffusion are increasing and both are complementary - one feed out other. An industry is defined as a group of firms producing products that are close substitute (Bettis \& Hitt, 1995). However technological advances have changed that definition and difficult to identify in which particular industry is in. This was the problem in modern technological adopters. However in Sri Lanka it is not difficult to identify industries as the diversity is not complex. Therefore it is not difficult to identify the trend in Sri Lanka in terms of technological innovation.

\subsubsection{Link between Occupational Structure and Entrepreneurship}

The link with occupational structure and entrepreneurship depends upon the selfemployment and innovative entrepreneurship and Thurik et.el. (2004) put these on the spectrum of entrepreneurship at lower end and upper end. He argues that increase in selfemployment retard the economic growth while innovative entrepreneurship accelerate the economic growth. In Sri Lanka liberalization policy had increase the import trade and personal service while discontinuing employment in indigenous small industry sector. Migration of unskilled labour to gulf region is not resulted from economic policy but made effective due to deregulation policies. Therefore occupational structure of the country is not resulted from liberalized economic policies (Kelagama, and Karunathilaka, 1999). Increase in import trade and personal service are in self-employment category and employment in organized sector do not contribute directly to entrepreneurship. Therefore level of entrepreneurship has to be determined by the distribution of self-employment which is categorized under un-organized sector. Expectation of the unemployed population shows that they are willing to engage in unproductive employment sector according to Thurik et.al (2002). 
Table 2.1 Distribution of Employees by Status of employment

\begin{tabular}{|c|c|c|c|c|c|c|c|c|c|c|}
\hline & \multicolumn{2}{|c|}{ Regular } & \multicolumn{2}{|c|}{ Casual } & \multicolumn{2}{|c|}{ Contractual } & \multicolumn{2}{|c|}{ Employer } & \multicolumn{2}{|c|}{$\begin{array}{l}\text { Self } \\
\text { Employed }\end{array}$} \\
\hline Employee & $\begin{array}{c}96 \\
2004\end{array}$ & & $\begin{array}{c}96 \\
2004\end{array}$ & & $\begin{array}{l}96 \\
200\end{array}$ & & $\begin{array}{l}96 \\
200\end{array}$ & & $\begin{array}{l}96 \\
2004\end{array}$ & \\
\hline Urban & 31.3 & 30. & 35 & 31 & 2.1 & 3 & 2.7 & 4.5 & 25.4 & 28.3 \\
\hline Rural & 18 & 18 & 33.5 & 34 & 2 & 1.6 & 1.3 & 1.5 & 33 & 35.3 \\
\hline Estate & 67.5 & 44.8 & 28.6 & 40.6 & 0.2 & 1.2 & 0 & 0.4 & 3.1 & 10.4 \\
\hline All & 22.8 & 21 & 33 & 34 & 1.9 & 1.8 & 1.4 & 1.7 & 30 & 33 \\
\hline
\end{tabular}

\section{Source: Consumer Finance and Socio-economic Survey 2003/2004}

\subsubsection{Conceptual Framework}

According to the reviewed literature following theoretical framework is built.

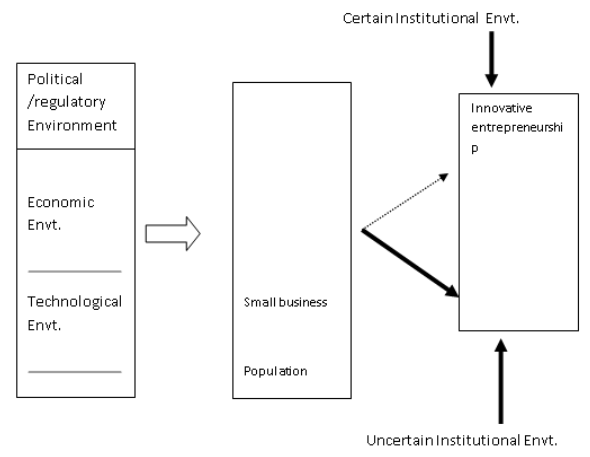

Fig. 1

\section{Methodology}

\subsection{Problem in Quantitative Research Approach:}

In this study case study method is used for following reasons: Macro economic studies are highly dependent on assumptions, models and approximations but using highly sophisticated analytical tools (statistical and econometrics techniques) to build deductive theories. Second problem is that interaction between institutional environment and

occupational structure has more variables than data point to one result (economic growth). Third problem is that it is difficult to define boundary between the context (institutional environment) and phenomenon (occupational structural change) are not clearly evident. Fourth problem is lack of prior theoretical proposition that establish relationship between occupational structure and economic growth in terms of entrepreneurship.

\subsection{Nature of Study}

This study is exploratory complemented with explanatory evidence. Therefore this study has ingredients of both exploratory and explanatory studies. For exploratory studies exemplary outcomes are needed in different locations with different socio economic context. It has to be proved similar outcomes from each case selected. In explanatory studies cause and effect relationship has to be established with an establishment of a theory at the outset. Theory development is essential before data collection. This is a point where case studies different from other methods such as ethnography and grounded theory.

\subsection{Choice of Case studies}

Thirteen case studies selected from 28 case studies for intensive observation and they were selected to reflect diversity in size, sector, location, and nature of entrepreneurship. Cases 1, 2, 5,6,12, and 13 are ethnographic case studies that had been associated with the author for some time. Cases 4, 7, 8, 9, 10, and 11 cases 
are selected to represent self-employment and innovative entrepreneurship which involved interviews, observation, occasionally participant observations. Five of them are innovative while other seven are solo entrepreneurs. Two firms are medium, another two are small according to international standards. Other seven are solo entrepreneurs. Ethnographic cases were studied for two years since 2006 and other case studies are carried out with repeated in-depth interviews, observations and collecting documentary evidence. It involved series of interviews, conversations with business partner's employees, and family in the cases of solo entrepreneurs.

\subsubsection{Brief Description of Cases}

* Case 1: Case one was about a youth who wanted to do business of his own but with new things. He started his business in 1986 motorcycle repairs initially then went to do contracts with the Mahaweli development area from 1986 to 1989. Then return to his former workshop and started making florescent tubes with his brother (case 2). Continued for another three years and still searching for opportunities. In 1991 he went to Mahaillluppalama Farm machinery Division (FMRC) and started making transplanters. On the partial subsidy offered by the FMRC he visited several countries including China and Australia. From Australia he show pre-fabricated iron frame and started manufacturing prefabricated frame. In 1994 he started making water browsers to supply water in the war-torn area in the east. In 1997 when the peace pact signed he started supplying water to local area using unsold water browsers. Currently he is doing pre-fabricated frames, water browsers manufacturing, and water suppliers to local area.

*Case 2: This is a case about youth who also wanted to do new business and continued to so until profit fell sue to invasion of imitators. Then in 1992 started supplying items to Ceylon Electricity Board and then to the department of education since it was profitable. Wince winning tenders and getting money is hard due to government rules and regulations he started a service station with the help of his wife's family's support.

Case 3: Case three was about a person who turned to be sand seller with the increased demand for sand with the environment regulations in 1996. First they did daily casual work and started sand mining in the Ma-oya in Dandugama lagoon. When there was discrepancy in sand transporting regulation in Western province and North Western province he decided to take advantage of the location which demarcated boundary between Western and North Western provinces. He mined sand in the North Western Province and sold in the Western province since Maoya was the boundary between two provinces.

Case 4: Activated carbon was a corporate business which came from large scale construction Company Link Engineering. It started in 1996 with an annual production 60 tons with existing technology and developed furnace technology through research and development and currently producing over 180 tons annually. Founders were charted engineers worked for Sate Engineering Corporation in 1992. Research and development was carried out by a graduate engineer.

*Case 5: Silencer producer started his business with his father who was a coconut charcoal wholesaler. He needed to start a business of his own search for such opportunity and found that Paper Corporation Valachinei needed used tires for their furnace. He started his business 
with the help of his father and bought a lorry to transport them. He used this lorry to transport salt form the Elephant Pass Salten. When the war broke out in 1986 he started importing re-conditioned motor cycles from Japan in 1990. When the business was flooded with new entrants he stated making silencers for popular models. In the meantime he heard about used Bedford engines and started to export Beford Engines to Canada while manufacturing silencers. Current he fell ill (paralyzed) but still managing his business satisfactorily

*Case 6: Case 6 was on a corporation employ who wanted independence and to start his own business. His skill were on manufacturing agricultural and cutlery implements in large scale but started contractual business by supplying earth to Land Reclamation Board in 1984. When money is hard to come started a record bar and tea shop in the heart of the town until 1996. When the business is not yielding enough he joined a company which sells re-conditioned consumer items in 1999. When he found that is hindrance to his independence he started selling garments which were discarded by garment factories. When the discarded items were fewer he started an again teashop close to a school.

Case 7: on a businessman who started business with the liberalized economic policies in 1989. First he worked as a manager of a timber depot then he started selling imported motor cycles at very small scale. Gradually he expanded his business and obtained the dealership for popular Indian brand and continuing his business only with this dealership.

Case 9: about canned fruit factory established with the foreign collaboration in an industrial Park. All the machinery \& technology is from Germany \& markets also provided by them. The factory collect fruits from the area, processed, canned and export.

Case 10, 11: on solo entrepreneurs who wanted to increase their income through lower risk business while doing their respective occupations. They have used coconut oil extraction and paddy-milling and used his family or relative of his to run the business until he returns form work.

*Case 12: was a youth that determined to do a business of his own since his school days. His argument was money is limited in government jobs and business is the only way one can earn as he performs. He started small scale hardware shop in 1993 and expended over the years. He migrated to Middle- East in 1996 and stayed there for two years to raise funds for his business and started hardware business. Most of the construction work is done by him and in 2005 he started a selling fruits since that was a traditional business in the area.

* Case 13: is on innovator who wanted to use the technology he knew. He resigned from his job in 1974 started a lathe work. Later he started manufacturing transformers with a high guarantee. He himself made a lathe machine by using local material since Lathe machines were very costly. With the frame work of import substitution policy government concentration was on cooperative and state corporations were instructed purchase things through co-operatives. To make use of the policy he joined cooperative which registered for producing small engineering components. The cooperatives get 5 to 10 percent commission from the sale. $\mathrm{He}$ got himself appointed as an office bearer and started his business and selling was through the cooperatives. With the import substitution policy he started manufacturing items for textile factories and started producing transformers in 
large scale. In the meantime he thought of value addition and looked for raw material which could be turned out to generate high values. Timber, granites, irons are the raw metrical he selected. In 1977 with the liberalized economy he starts first with importing motor cycles and then went on importing lathe machines form Taiwan. In the meantime he started granite polishing industry.

Table 3.1 Changes in institutional Environment in Chronological Order

\begin{tabular}{|c|c|c|}
\hline Year & $\begin{array}{l}\text { Changes /shocks in the } \\
\text { Institutional environment }\end{array}$ & Possible Effects on Entrepreneurship \\
\hline 1960 & $\begin{array}{l}\text { Per capita Income is nearly } \\
\text { equal to South Korea }\end{array}$ & High wealth creating potential \\
\hline $1965-70$ & $\begin{array}{l}\text { Partial liberalization and } \\
\text { export oriented liberalization }\end{array}$ & Possibility of producing for export markets \\
\hline 1971 & Insurrection Activities of JVP & Uncertainty about future of the business \\
\hline 1971 & $\begin{array}{l}\text { Inward looking protectionism } \\
\text { policy }\end{array}$ & $\begin{array}{l}\text { Contraction/expansion of firms } \\
\text { Rent-seeking entrepreneurship could emerge }\end{array}$ \\
\hline 1972 & $\begin{array}{l}\text { Land reform act and land } \\
\text { ceiling, Food self sufficiency }\end{array}$ & $\begin{array}{l}\text { Tendency to produce agricultural implements } \\
\text { and engage in food production }\end{array}$ \\
\hline 1976 & $\begin{array}{lll}\text { Unemployment } & \text { rate } 24 \\
\text { Percent } & & \\
\end{array}$ & Moving towards low capital self-employment \\
\hline 1977 & $\begin{array}{l}\text { General Election -UNP gets } \\
\text { two-third majority }\end{array}$ & Unce \\
\hline 1978 & Liberalization of the Economy & $\begin{array}{l}\text { Lost jobs in small-engineering firms and hand } \\
\text { looms section. Increased import trade }\end{array}$ \\
\hline 1979 & Removal of Food Subsidy & $\begin{array}{l}\text { Moving away from agricultural projects and } \\
\text { occupations }\end{array}$ \\
\hline $\begin{array}{l}1981- \\
1986 \\
\end{array}$ & $\begin{array}{l}\text { Migration to gulf region (1.3 } \\
\text { million) }\end{array}$ & $\begin{array}{l}\text { Ease unemployment and move towards self- } \\
\text { employment }\end{array}$ \\
\hline 1983 & North ethnic conflict & $\begin{array}{l}\text { Migration of employable Tamils; other groups } \\
\text { acquire vacant opportunities }\end{array}$ \\
\hline 1985 & $\begin{array}{l}\text { Mahaweli development } \\
\text { programme huge expenditure } \\
\text { on government projects }\end{array}$ & $\begin{array}{l}\text { Entrepreneurship could turned towards } \\
\text { engaged in contractual works; moving away } \\
\text { from innovative entrepreneurship }\end{array}$ \\
\hline 1987 & $\begin{array}{l}\text { Inflation } \quad \text { CCPI: } \quad 652.8 \text {; } \\
\text { GDPD: } 38.4\end{array}$ & $\begin{array}{l}\text { Uncertainty about future of products and } \\
\text { services; more individuals may seek small } \\
\text { business as self-employment }\end{array}$ \\
\hline $\begin{array}{l}1987 \\
1989\end{array}$ & $\begin{array}{l}\text { Insurrection activities; } \\
\text { Stabilization programme }\end{array}$ & $\begin{array}{l}\text { Uncertainty prevailed: no incentive for } \\
\text { entrepreneurship }\end{array}$ \\
\hline 1989 & $\begin{array}{l}\text { Second wave of liberalization } \\
: \text { FDI liberalization and } \\
\text { privatization }\end{array}$ & $\begin{array}{l}\text { Ease unemployment, increased personal } \\
\text { service, incentive for self-employment in } \\
\text { export oriented firms }\end{array}$ \\
\hline 1990 & $\begin{array}{l}\text { Industrial promotion Act } \\
200 \text { readymade garment } \\
\text { programme }\end{array}$ & $\begin{array}{l}\text { Incentives for self-employment and wage } \\
\text { employment; Rent seeking attitude to get the } \\
\text { benefit of BOI incentives }\end{array}$ \\
\hline
\end{tabular}




\section{Results and Discussions}

Findings are categorized with respect to the incentives for self-employment and innovative entrepreneurship according to the evidence from case studies. Since macroeconomic variables are numerous, important events are listed in the Table 5.1 from 1971 to 2005 where incentives and dis-incentives were provided for innovative entrepreneurship which improves the sustainable economic growth rate.

\subsection{Incentives for self- employment \& innovative entrepreneurship}

Case 1 and case two are brothers who wanted to create innovative ventures. First they started the workshop in 1986 and then went into undertake contracts in Mahaweli development programme. When those contracts dried up returned to the former venture and started producing florescent tubes for household lighting in 1992. This period coincides with the highest industrial growth. In 1993 Case 2 started manufacturing school chairs due the public investment programme launched by the government which is an innovative venture. In 1995 with new government all these public investment programme discontinued and case decided to start a service station which is a personal service which does not provide great value addition to the labor.

Case 1 also abandoned the tube-light production and embarks into prefabricated Steel frame which is an innovative firm that started in 1994 with the experience he got from visiting Australia. This period coincides with the highest industrial growth period and the environment was relatively stable. Again he started producing water browsers in 2000 as a result of war which hampered water supply to East. War was an incentive for innovative entrepreneurs.
Case 3 was a unique example for rent seeking entrepreneurship. The environmental laws which had been enforced differently had used by case three to do his business buy mining sand in the North Western Province illegally and transporting them legally in the Western Province.

Case 5 abandoned his contractual business due to the trade liberalization policy and embarked into importing used motorcycles in 1979. This is where innovative entrepreneurship tuned into self-employment which gives less value addition. Once new entrants flooded to the business he chooses to produce silencers for used motorcycles in 1992 which is an innovative entrepreneurship.

Case 4 is an example of innovative corroborative entrepreneurship which started producing activated carbon with local technology and improved its productivity through research and development. The incentives provided by the BOI was an incentive them for finding market and import capital equipment. Comparing case 4 with case 9 it shows induced innovative entrepreneurship by foreign direct investment. Almost all capital equipment and markets were provided by the foreign partner in Germany. This started in 1991 and used BOI incentives and Industrial policy which established industrial parks in seven provinces. These venture hadn't effect on price fluctuation and labour laws were less effective in industrial parks.

Cases 6 and 7 are on solo enterprises stimulated by the government policy on public investment and import and export liberalization. Even though they wanted to do innovative enterprises they choose retail trade due to low-capital and import liberalization. 
Case 10 and 11 are typical solo entrepreneurs who wanted to exploit profit from low-risk, comparatively higher capital, less vulnerable to environmental shocks. They choose oil extractions and paddy, milling those have low risk and both rice and coconut oil are essential commodities of the people. They used personal loans provided by respective institutions (Bank and Local Government Office) to get the capital equipment.

Case twelve was an entrepreneur who had an opportunity to find a job but choose business owing to its return for the effort you put. The commodity he selected was resistant to price fluctuations and had less effect from the changing environment. However he is innovative since he started fruit business which has no relationship with hardware.

Case 13 is a case which has both innovative and rent seeking entrepreneurship qualities and who extracted profit from changing environment. $\mathrm{He}$ started his business making transformers and with the onset of import substitution. Since he is innovative and rent seeking, decide to join a light engineering cooperative to find market for his products in state enterprises (Textile Corporation). $\mathrm{He}$ used to produce goods in his factory and used sell products made by the cooperative. With the onset of liberalization policy he started importing lathe machines, motor cycles and other equipment while making transformers. In the meantime he started capital intensive venture making polished granite. He chooses this venture to keep away from new entrants and availability of raw material. This example gives how to maintain solo and innovative entrepreneurship to diversify his portfolio.

\subsection{Incentives for innovative or non- innovative entrepreneurship}

Table 4.1 Incentives for solo
entrepreneurship and innovative
entrepreneurship

\begin{tabular}{|c|c|c|}
\hline 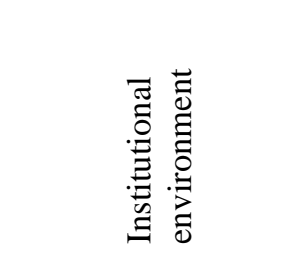 & 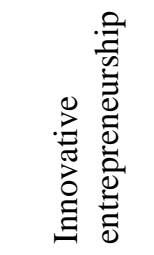 & 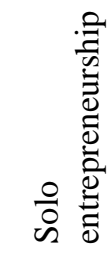 \\
\hline $\begin{array}{l}\text { 1972-1977 } \\
\text { (Protectionism) }\end{array}$ & $\begin{array}{l}\text { Case } 1,2, \\
5, \text { and } 13\end{array}$ & \\
\hline $\begin{array}{l}1978-1983 \\
\text { (Liberalized } \\
\text { economy) }\end{array}$ & Case 7 & Case 6 \\
\hline $\begin{array}{l}\text { 1994- } 2005 \\
\text { (Liberalized } \\
\text { economy with } \\
\text { ethnic conflicts }\end{array}$ & $\begin{array}{ll}\text { Case } & 3, \\
\text { Case } & 4, \\
9, & \end{array}$ & $\begin{array}{l}10, \\
\text { and } 11\end{array}$ \\
\hline
\end{tabular}

* Case 8 is omitted

Table 4.2 Entrepreneurship turned to solo from innovative due to institutional environment

\begin{tabular}{|c|c|c|}
\hline 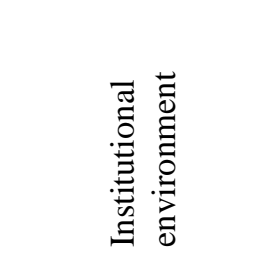 & 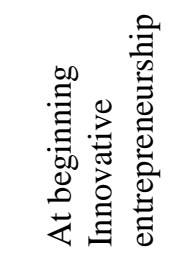 & 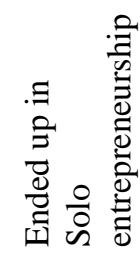 \\
\hline $\begin{array}{l}1972-1977 \\
\text { (Protectionism) }\end{array}$ & $\begin{array}{l}\text { Case 1,2, } \\
\text { and } 13\end{array}$ & $\begin{array}{l}\text { Case } 2, \\
5, \quad \text { and } \\
\text { case } 13\end{array}$ \\
\hline $\begin{array}{l}1978-1983 \\
\text { (Liberalized } \\
\text { economy) }\end{array}$ & Case 7 & $\begin{array}{l}\text { Case } 6, \\
\text { Case } 7,\end{array}$ \\
\hline $\begin{array}{l}\text { 1994- } 2005 \\
\text { (Liberalized } \\
\text { economy with } \\
\text { ethnic conflicts }\end{array}$ & $\begin{array}{l}\text { Case 3, 4, } \\
9 \text {, }\end{array}$ & $\begin{array}{l}\text { Case } \\
10,11,\end{array}$ \\
\hline
\end{tabular}

From the table 5.1 and 5.2 one can find how innovative entrepreneur became solo entrepreneurs due to environmental 
incentives. The above regimes were selected to control variable. 1972 to 1977 period was a period without ethnic problem so that the period 1978 to 1983 . The major difference between these two is closed economy and opened economy. Period from 1994 to 2005 was a time with liberalized economy with ethnic and insurrection activities along with policy adjustments. Case 7 started his business in liberalized economy and remained there without becoming an innovative one. Case 3 was rent seeking entrepreneur who used to explore slacks in legal system to derive profit. Case 3 and 4 are innovative entrepreneurs who had foreign market opportunities and continued their business to gain profit. Innovative entrepreneurship in 172-77 period became solo entrepreneurship with the liberalized economy.

\section{Conclusion}

From the results of analyzing cases and across cases it is evident that major reason for not moving entrepreneurs toward for more wealth creating opportunities is the uncertainty of institutional environment particularly the political environment which influence changes in economic policies from time to time. As a result, entrepreneurs' business life-cycles may coincide with the political cycle of leading political parties. This truncating business cycle due to uncertainty may adopt survival strategies and may move towards lower end of the innovative spectrum. As a result the number of population engaged in small business may not attempt to exploit more wealth creating opportunities and remain in low wealth creating opportunities. As a result there could be a mismatch between occupational structure and economic structure which in turn influence uneven economic growth.
Limitation of this study is the using inductive approach to explain an economic phenomenon which majority believe not appropriate. However this is an exploratory study which paves way for economist investigates findings of this study quantitatively and with more sophisticated tools.

\section{References}

Abeyrathna, S. (1997). 'Trade Strategy and industrialization' In; W. D. Lukshman (ed.), Dilemmas in Development, Sri Lanka Association of Economists, Colombo.

Abeyratne, S. (1993). Anti-export Bias in the Export Oriented Economy of Sri Lanka

Ahuja, H. L. (1997). Analysis of Economic Systems and Microeconomic Theory, S. Chand \& company, New Delhi.

Athukoral, P. and Rajapathirana, S. (2000). Liberalization and Industrial Transformation: Sri Lanka in International Perspective, Oxford University Press, New Delhi

Central Bank Annual Reports, Various Issues, Central Bank of Sri Lanka, Colombo

Chandrasiri, S. (2008). Industrial Development and Poverty Reduction Experience in Sri Lanka, In Development Perspectives: Growth and Equity in Sri Lanka (Eds) S. M. P. Senanayke, W. Wimalarathna, and Amala de Silva, Department of Economics, University of Colombo.

Consumer Finance and Socio-Economic Survey (2003/4). Central Bank of Sri Lanka, Colombo.Department 
of Census and Statistics (various years). Annual Survey of Industries, Government Publication Bureau, Colombo

Fadahunsi, A. and Rosa, P. (2002). Entrepreneurship amd Illegality: Insight from the Nigerian crossborder Trade, Journal Business Venturing, 17:397-429

Hitt, M. A. and Reedm T. S. (2000). Entrepreneurship in New Competitive Landscape (In: . Entrepreneurship as Strategy) Meyer, G.D. \& Heppard, K. A. (eds.). Sage: London.(2000).

Kelagama, S. (2006). Development under Stress: Sri Lankan Economy in Transition, Vijitha Yapa, Sri lanka

Kelegama, S. (1997). Privatization: An overview of the Process and Issues (Eds) Lakshaman, W. D. (1997). Dilemas of Development, Sri Lanka Association of Economists.

Morse, E. A. \& Michell, R. (2006). Cases in Entrepreneurship: Venture Creation Process, Sage: New Delhi.

Nua (2000). Retrived from World Wide Web, February 2004, at http://www.nua.ie/surveys/howmany-online/index.html.

Pieris, M. P. (1997). Economic Growth, and Structural -Institutional Change since Independence, (Eds) Lakshaman, W. D. (1997). Dilemas of Development, Sri Lanka Association of Economists.

Sanderathne, N. (2000). Economic Growth and Social Transformation, Tamarind Publications, Colombo.
Upananda, W. A. and Kumara, UES (2014). 'How Does Institutional Context Influence Entrepreneurial Process of Sri Lankan Small Businesses?' . Ruhuna Journal of Management and Finance, 1(2), July 2014.

Wennekers, S. and Thurik, R. (1999). Liking entrepreneurship and economic growth, Kluwer Academic Publishers, Netherland.

Wennekers, s. Stel, A.V., Carree, M. Thurik, R. (2008). The relation between entrepreneurship and economic development: is it Ushaped? SCALES, EIM, the Netherlands.

Yin, R. K. (2003). Application of Case Study Research, Sage: Thousand Oaks

Yin, R. K. (2003). Case Study Design and Methods, Sage: Thousand Oaks 


\section{Appendices}

Table 1.1.Sectorial Composition of GDP at constant factor Cost (1996) - \%

\begin{tabular}{|l|l|l|l|l|l|l|l|}
\hline Sector & 1950 & 1960 & 1970 & 1980 & 1990 & 2000 & 2006 \\
\hline Agriculture & 42.4 & 39.3 & 35.5 & 31.3 & 27.8 & 20.5 & 17.2 \\
\hline Industry* & 19.0 & 18.9 & 23.4 & 23.0 & 23.4 & 27.6 & 27.0 \\
\hline Service & 38.6 & 41.8 & 41.1 & 45.7 & 48.8 & 51.9 & 55.8 \\
\hline Total & 100 & 100 & 100 & 100 & 100 & 100 & 100 \\
\hline
\end{tabular}

- $\quad$ include mining \& quarrying, construction and electricity, gas, and water Source: Sunil Chnadrasiri, Development Perspectives, 2008: 45)

Table 1.2 Employment and Output Share in the Sri Lankan Economy

\begin{tabular}{|l|l|l|l|l|l|l|l|l|l|}
\hline \multicolumn{2}{|c|}{1971} & \multicolumn{2}{l|}{1981} & \multicolumn{2}{l|}{1985} & \multicolumn{2}{l|}{1990} & \multicolumn{2}{l|}{1995} \\
\hline $\begin{array}{l}\text { GDP } \\
\text { Share }\end{array}$ & Empl. & $\begin{array}{l}\text { GDP } \\
\text { Share }\end{array}$ & Empl. & $\begin{array}{l}\text { GDP } \\
\text { Share }\end{array}$ & Empl. & $\begin{array}{l}\text { GDP } \\
\text { Share }\end{array}$ & Empl. & $\begin{array}{l}\text { GDP } \\
\text { Share }\end{array}$ & Empl. \\
\hline 28.3 & 50.1 & 24.6 & 51.2 & 27.7 & 49.3 & 26.9 & 47.7 & 20.5 & 40.0 \\
\hline 17.4 & 9.7 & 17.0 & 14.1 & 17.0 & 13.9 & 16.4 & 15.7 & 22.2 & 14.8 \\
\hline 16.7 & 9.3 & 13.6 & 12.4 & 14.7 & 12.6 & 14.3 & 14.1 & 19.9 & 14.00 \\
\hline 0.7 & 0.4 & 3.4 & 1.7 & 2.3 & 1.3 & 2.1 & 1.6 & 2.5 & .8 \\
\hline 54.3 & 40.2 & 58.4 & 34.7 & 55.3 & 36.8 & 56.7 & 36.6 & 57.4 & 41.3 \\
\hline
\end{tabular}

Source: Kelegama (2006: 263)

Table 1.3 Distribution of Occupational Categories - India

\begin{tabular}{|l|l|l|l|}
\hline Occupational Category & 1971 & 1981 & 1991 \\
\hline Primary occupation (Agriculture) & 72.1 & 68.83 & 66.75 \\
\hline $\begin{array}{l}\text { Secondary Occupation } \\
\text { (Industry) }\end{array}$ & 11.2 & 13.54 & 12.75 \\
\hline $\begin{array}{l}\text { Tertiary Occupation } \\
\text { (Service) }\end{array}$ & 16.7 & 17.63 & 20.50 \\
\hline
\end{tabular}

Source: Census of India (1991)

Table 1.4 Structure of Indian Economy by Sectors

\begin{tabular}{|l|l|l|l|l|l|l|}
\hline Sector & $1950-51$ & $1960-61$ & $1970-71$ & $1980-81$ & $1990-91$ & $1994-95$ \\
\hline Agriculture & 56.4 & 54.0 & 45.8 & 39.7 & 33.4 & 31.3 \\
\hline Industry & 15.0 & 17.0 & 22.3 & 24.4 & 27.0 & 27.5 \\
\hline Services & 28.5 & 28.0 & 31.8 & 36.0 & 39.6 & 41.2 \\
\hline
\end{tabular}

Source: Census of India (2000) 